\title{
НАВЧАЛЬНО-МЕТОДИЧНА БАЗА ДЛЯ ВИВЧЕННЯ УКРАЇНСЬКОЇ МОВИ ЯК ІНОЗЕМНОЇ НА ПІДГОТОВЧОМУ ВІДДІЛЕННІ
}

\author{
НІНА ДАНИЛЮК \\ Східноєвропейський національний університет імені Лесі Українки, Луцьк - Україна \\ nina.danylyuk@gmail.com; ORCID: 0000-0002-7373-2902
}

ТЕТЯНА МАСИЦЬКА

Східноєвропейський національний університет імені Лесі Українки, Луцьк - Україна masytska@gmail.com; ORCID: 0000-0002-2375-1179

\section{PODSTAWY DYDAKTYCZNO-METODYCZNE NAUCZANIA JĘZYKA UKRAIŃSKIEGO JAKO OBCEGO W ODDZIALE PRZYGOTOWAWCZYM}

\author{
NINA DANYLUK \\ Wschodnioeuropejski Uniwersytet Narodowy imienia Łesi Ukrainki, Łuck — Ukraina \\ TETIANA MASYĆKA \\ Wschodnioeuropejski Uniwersytet Narodowy imienia Łesi Ukrainki, Łuck — Ukraina
}

STRESZCZENIE. Badanie przeprowadzono w ramach kierunku metody nauczania języka ukraińskiego jako obcego. Istotność badania warunkuje potrzeba systematyzacji materiału. Celem badania jest charakterystyka wyposażenia dydaktyczno-metodycznego, którym dysponują wykładowcy Wschodnioeuropejskiego Uniwersytetu Narodowego im. Łesi Ukrainki w nauczaniu języka ukraińskiego jako obcego w oddziale przygotowawczym. Artykuł wyjaśnia zasady teoretyczne, wyznacza główne pojęcia metodyki nauczania języka ukraińskiego jako obcego, takie jak: zasada, podejście, metoda, sposób. Dokonano przeglądu tradycyjnych i nowych metod oraz podejść nauczania, podręczników, słowników niezbędnych na początkowym etapie nauki języka ukraińskiego, zwrócono uwagę na metody interaktywne, zintegrowanie podejść komunikacyjnego i językowo-krajoznawczego.

Słowa kluczowe: metoda nauczania języka ukraińskiego jako obcego, podstawy dydaktycznometodyczne, wyposażenie dydaktyczno-metodyczne, metody i sposoby nauczania, podręczniki, słowniki 


\title{
EDUCATIONAL METHODOLOGICAL BASIS FOR TEACHING UKRAINIAN AS A FOREIGN LANGUAGE AT THE PREPARATORY DEPARTMENT
}

\author{
NINA DANYLYUK \\ Lesya Ukrainka Eastern European National University, Lutsk — Ukraine \\ TETIANA MASITSKA \\ Lesya Ukrainka Eastern European National University, Lutsk — Ukraine
}

\begin{abstract}
ABSRACT. The study has been conducted in the field of methods of teaching Ukrainian as a foreign language. Its topicality has been caused by the necessity to process the collected relevant data. The purpose of the study is to describe educational methodological materials used by lecturers of Lesya Ukrainka Eastern European National University in order to teach Ukrainian as a foreign language at the Preparatory Department. The article reveals a theoretical basis and defines key terms in the field of methods of teaching Ukrainian as a foreign language, such as a principle, an approach, a method and a mode. A overview of the traditional and new methods and modes of teaching as well as textbooks, manuals and dictionaries used at the elementary level of teaching / learning Ukrainian is carried out. A special attention is paid to the application of the interactive methods, combination of communicative and linguistic cultural approaches.
\end{abstract}

Key words: methods of teaching Ukrainian as a foreign language, educational methodological basis, methods and modes of teaching, textbooks, manuals and dictionaries

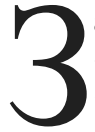

а статистичними даними, в українських вищих навчальних закладах у 2017/2018 н.р. здобували освіту близько 62 тис. іноземців. У Східноєвропейському національному університеті імені Лесі Українки протягом 2009-2018 pр. на рівні довузівської мовно-фахової підготовки (на підготовчому відділенні), за освітньо-кваліфікаційними рівнями "бакалавр" і “магістр" на різних факультетах (переважно міжнародних відносин, економічному, юридичному, математичному /зараз факультет інформаційних систем, фізики та математики/, біологічному, географічному, факультеті психології /зараз факультет психології та соціологіï/), а також в аспірантурі навчалися громадяни Республіки Білорусь, Болгарії, Російської Федерації, Литви, Республіки Польща, Азербайджану, Узбекистану, Республіки Конго, Республіки Сенегал, Федеративної Республіки Нігерія, Намібії, Зімбабве, Алжиру, Сирії, Держави Лівія, Гани, Того, Замбії, США, Китаю. Викладене вище, потреба систематизування матеріалів щодо викладання української мови як іноземної визначають актуальність підготування відповідного методичного забезпечення та добору методів роботи на кожному етапі навчання. 
У цій статті йтиметься про аналіз методичного забезпечення навчання української мови як іноземної на підготовчому відділенні Східноєвропейського національного університету імені Лесі Українки (далі СНУ імені Лесі Українки), результати якого, як видається, будуть корисними для колег з інших закладів вищої освіти (далі ЗВО). Це дослідження виконано в рамках напряму методики викладання української мови як іноземної. Отже, мета статті описати навчально-методичне забезпечення вивчення української мови як іноземної на підготовчому відділенні. Завдання - розглянути й систематизувати основні матеріали з методики навчання української мови як іноземної, які використовують викладачі СНУ імені Лесі Українки.

Методика викладання української мови як іноземної (далі УМІ) в Україні почала формуватися, як відомо, у 50-60-і pp. ХХ ст. (Ю. Жлуктенко, Н. Тоцька та ін.), відповідно розвивалася в 70-80-і pp. (Г. Макарова, Г. Онкович, Н. Присяжнюк, Л. Паламар та ін.). Упродовж 90-х рр. XX - на поч. ХХІст. ця робота активізувалася. У зв' язку зі значним збільшенням кількості іноземців, які почали вивчати українську мову, відкрито низку спеціальних кафедр у Київському національному університеті імені Тараса Шевченка, Львівському національному університеті імені Івана Франка, НТУ „Київський політехнічний інститут імені Ігоря Сікорського”, НТУ „Харківський політехнічний інститут" та ін.

За кордоном уже тривалий час успішно працюють кафедри або відділи україністики, зокрема в Ягелонському університеті в Кракові, Варшавському університеті, Університеті імені Адама Міцкевича в Познані, Університеті Марії Складовської-Кюрі в Любліні (Польща), Софійському університеті (Болгарія), Пряшівському університеті (Словаччина), Університеті Палацького в Оломоуці та Празькому університеті (Чехія), УВУ в Мюнхені, інститутах славістики Лейпцизького університету й Університеті імені Мартіна Лютера в Галле (Німеччина), Університеті Париж IV (Франція), Кембриджському університеті (Великобританія), Альбертському, Оттавському, Торонтському й Манітобському університетах (Канада), Гарвардському, Стенфордському та Колумбійському університетах (США), Університеті іноземних мов Хангук у Сеулі (Південна Корея) та ін. Серед провідних українських методистів назвемо С. Воробйову, Н. Зайченко, І. Кочан, Н. Станкевич, О. Туркевич, Г.Швець та інших, які узагальнили результати своєї практичної роботи в статтях, посібниках, словниках, дисертаційних працях. До розвитку теорії методики викладання УМІ та реалізування іiі на практиці долучилися зарубіжні дослідники: С. Амір-Бабенко, Г. Бідер, І. Гук, А. Гумецька, М. Кавецька, Й. Капралі, Е. Кучарська, Й. Співак, Б. Шкандрій, Д. Ярчак та ін. Однак чимало методичних напрацювань потребують систематизування, уточнення щодо традиційних і новітніх методів навчання.

Наголосімо, що в Україні опубліковано низку видань з методики викладання УМІ: збірник матеріалів міжнародної конференції Українська мова як 
іноземна: проблеми методики викладання (Львів 1994), І. Кочан, Н. Захлюпана Словник-довідник з методики викладання української мови (Львів 2005), Навчальні програми та методичні рекомендачії до дисииплін спеціалізачії „Українська мова як іноземна” (Київ 2015) та ін. Важливим досягненням стало видання щорічного збірника Теорія і практика викладання украӥнської мови як іноземної (Львів 2006-2017), у якому є розділ з методики викладання УМI. Про становлення методики УМІ писали І. Кочан та Г. Швець [Кочан 2012; Швець 2013]. Т. Космеда здійснила огляд методичного забезпечення для польських студентів [Космеда 2017]. Значний внесок у розвиток методики викладання УМІ зробили Г. Онкович та Л. Паламар (зокрема вони є авторами докторських дисертацій та монографії [Онкович 1995; Паламар 1997]), а також О. Туркевич (авторка кандидатської дисертації [Туркевич 2012] і кількох статей з проблеми формування термінолексики з методики УМІ [Туркевич 2012]). Укладачі методичних праць орієнтуються на Навчальні мінімуми з украӥнської і російської мов для іноземиів, укладені Н. Зайченко й С. Воробйовою (Київ 1995), а також на Державний стандарт з украӥнської мови як іноземної. Рівні A1-C1 (Київ 2014), Загальноосвітній стандарт з украӥнської мови як іноземної (Київ 2014) та комплекс програм, розроблених відповідно до рівнів володіння європейськими мовами: A1 - початковий рівень, А2 базовий рівень; В1 - I середній рівень; В2 - II середній рівень; С1 — професійний рівень (наказ МОН України від 24.06.2014р.). Використовуючи названі матеріали, автори цієї статті підготували й видали працю Украӥнська мова як іноземна: робоча програма нормативної навчальної дисципліни для слухачів-іноземиів підготовчого відділення (Луцьк 2015, 2016, 2017, 2019), яку використовують у СНУ імені Лесі Українки, тексти й методичне забезпечення для практичних занять та екзамену.

Отже, на сьогодні маємо чималі досягнення в галузі методики викладання УМІ. Визначальним для навчання УМІ $є$ ключові поняття принщип, niдxid, метод, прийом, зміст яких з'ясовують такі вчені: А. Бронська, Н. Зайченко, В. Маковська, Л. Мацько, Т. Кудіна, Б. Сокіл, Г. Строганова, О. Туркевич та ін. [Зайченко1995; Бронська 2000; Сокіл 2007; Строганова 2008; Мацько, Кудіна 2011; Туркевич 2012]. Терміносполученням принципи навчання дослідники позначають основні, вихідні положення, що зумовлюють особливості викладання УМІ. Загальні лінгводидактичні принципи навчання такі: свідомість, наочність, науковість, системність, доступність, активність, креативність, колективність. Крім того, у процесі викладання УМІ послуговуються принципами активної комунікації практичної спрямованості, краӥнознавчої інформативності, надання переваги рідній мові, новизни, концентризму, а також комунікативно-ситуативним принципом. Важливий чинник - урахування мотиваційної, вікової, географічної, культурної, соціальної, мовної специфіки контингенту іноземців. Зауважмо, що комунікаиія - засадничий 
принцип і метод викладання УМІ. Навчальний матеріал організовують за двома змістовими лініями: комунікативно-мовленнєвою та мовною. Навчання УМІ підпорядковане практичній меті — оволодіння мовою як засобом спілкування в повсякденному житті й отримання професійної освіти в Україні. Це визначає функційний підхід до відбирання й подання мовних одиниць, їхнє ситуативно-тематичне репрезентування та укладання текстотеки.

Прийомами навчання називають конкретні дії та операції викладача безпосередньо в процесі навчання, тобто спосіб пояснення навчального матеріалу, зокрема це опис, порівняння, зіставлення, семантизування та ін. Термін niдxid об'єднує сукупність понять на позначення „,системної організації процесу передавання та засвоєння знань, що об'єднує всіх суб'єктів навчання - викладача і студента" [Строганова 2008: 173]. Відповідно до цього в методиці УМІ виділяють екстралінгвістичний, системний, комунікативний, функційний, діяльнісний, індивідуальний, особистісний, комплексний, компетентнісний, культурологічний підходи та підхід взаємопов 'язаного навчання, що відіграють визначальну роль у навчанні мови на початковому етапі та підготуванні методичного забезпечення. Наголосімо, що інколи зміст понять “"пинцииn” та “niдxid” дослідники ототожнюють.

Meтод (від грец. metodos “шлях дослідження, пізнання”) — „система правил і прийомів підходу до вивчення явищ і закономірностей природи, суспільства і мислення; шлях, спосіб досягнення певних результатів у пізнанні і практиці, тобто спосіб організації теоретичного і практичного освоєння дійсності" [Кочерган 2006]. Спираючись на класифікацію М. Кочергана [Кочерган 2006], науковці виділяють філософські, загальномовні та лінгвістичні методи мовознавчих досліджень. Як зауважує О. Туркевич [Туркевич 2012], методична терміносистема об'єднує кілька тематичних класів термінів 3 методики викладання УМІ: а) власне методичні; б) лінгвістичні; в) психолого-методичні; г) соціокультурні. Найбільш поширені такі традиційні методи навчання іноземних мов: граматико-перекладний, усвідомлено-зіставний, аудіолінгвальний, аудіовізуальний, усвідомлено-практичний, комунікативний [Туркевич 2012]. Їхнє використання у вітчизняній методиці для опанування іноземних мов стало традиційним [Гнаткевич 1999], а з 90-х рp. ХХ ст. і для вивчення УМІ. Вони засвідчили свою ефективність й охоплюють такі складники (подаємо в стислому вигляді): 1) граматико-перекладний (словниковий запас і знання граматики формуються на основі художніх, суспільно-політичних текстів, що містять правильні граматичні форми); 2) усвідомлено-зіставний (порівняння подібних і відмінних мовних явищ в українській та рідній мовах); 3) аудіолінгвальний (багаторазове прослуховування й промовляння мовних зразків); 4) аудіовізуальний (вивчення базових конструкцій, найчастотніших одиниць, моделей вербальної та невербальної поведінки); 5) усвідомлено-практичний (навчання мови за чотирма видами комунікатив- 
ної діяльності: читання, письмо, говоріння, аудіювання); 6) комунікативний (розвиток мовленнєво-мисленнєвої активності студентів і вивчення та закріплення нового матеріалу в процесі спілкування) [Сокіл 2007]. До них активно вдаються викладачі УМІ на підготовчому відділенні СНУ імені Лесі Українки й на інших етапах вивчення мови. Перелік методів та прийомів навчання УМІ ще не усталений, чіткого розмежування між методами й прийомами, принципами та підходами також не проведено.

Одна 3 основних характеристик методичної роботи на сучасному етапі - перенесення акценту з інформаційного навчання на оволодіння методами комунікації, розвивання в іноземних слухачів і студентів здатності до набуття нових знань. Щоб активізувати комунікативну діяльність іноземців, не лише використовуємо різноманітні методи навчання, а й поєднуємо з інноваційними методами такі усталені методи / прийоми: пояснювально-ілюстративний (розширення словникового запасу й побудова синтаксичних одиниць на основі роботи з ілюстраціями, репродукціями, зразками, схемами тощо), репродуктивний (відтворення в процесі спілкування засвоєних лексичних і граматичних одиниць), проблемного викладу (вивчення нового матеріалу будується навколо відповідної важливої для аудиторії проблеми), частковопошуковий (слухачі самостійно встановлюють значення лексем за словниками, намагаються з'ясувати їх за контекстом, шукають синоніми й антоніми, на основі наведених зразків виводять граматичні правила тощо), дослідницький (слухачі виконують невеликі індивідуально-дослідні завдання, напр., за перекладним словником встановлюють спільні лексичні одиниці в українській та рідній мовах; виокремлюють групи власних назв географічних об'єктів та власних імен людей; шукають паралелі в етикетних формулах української та рідної мов, у граматичних формах, побудові синтаксичних конструкцій тощо). Серед інноваційних методів застосовуємо такі: 1) інтерактивні методи (створення на занятті невимушеного спілкування студентів та викладача або студентів між собою, творче моделювання певних ситуацій, виконання невеликого проекту, рольові ігри, інтерв'ювання, “мозковий штурм”, “дерево рішень”, “акваріум”, “кейсметод" тощо); 2) використання нових технічних засобів навчання комп'ютерних та мультимедійних, мережі інтернет (доцільні для контролю знань, зберігання й застосування навчальних лексичних матеріалів, підготування проектів чи презентацій про країну тощо); 3) позааудиторне ситуативно-тематичне вивчення мови (засвоєння лексики й граматики в різних сферах офіційного та побутового спілкування: у магазині, касі, кіоску; на пошті, у банку; у ресторані, кафе, їдальні; у бібліотеці; в адміністративних установах; на вулиці, у транспорті; у театрі, музеї, на екскурсії; у поліклініці, в аптеці тощо); 4) інклюзивний метод (залучення до занять для іноземців українських студентів i, відповідно, іноземців - до лекцій і практичних занять для українців) та ін.; 5) метод культурно-масо- 
вої активності / діяльності (заохочення до участі в проведенні державних, громадських, народних свят, університетських заходів, напр.: Дня освітянина, Андріївських вечорниць, Різдва, Нового року, свята Валентина, днів народження Лесі Украӥнки й Т. Шевченка, Паски, випускного вечора тощо).

Спираючись на усталену структуру заняття (повторення вивченого, сприймання нового матеріалу, засвоєння, узагальнення), а також на поширені етапи опрацювання нової лексики (презентація, інтерпретація, семантизація, засвоєння, повторення й контроль за якістю іï вивчення), у роботі з іноземцями на початковому етапі вдаємося до незвичних форм і прийомів. Серед них назвемо такі: “Поширити речення” (на місці пропущених слів поставити потрібні одиниці), “Вилучити зайве” (у складі речення забрати надлишкові слова), “Роз’єднати слова” (у реченні, записаному без міжслівних проміжків, виокремити відомі слова), “Завершити фразу” (у незакінчених реченнях поставити потрібні слова, щоб вони стали закінченими), “Зробити комплімент” (з наведених зразків вибрати комплімент дівчині, хлопцеві, другові, мамі...), “Прогноз погоди" (на основі даних про температуру, напрям і силу вітру, хмарність підготувати прогноз погоди), “Асоціації" (до написаних або названих слів-стимулів дібрати слова-асоціаціі), “Алфавіт” (до кожної букви алфавіту записати / назвати якомога більше відомих слів), "Пояснити значення імені" (за словником власних імен людей пояснити значення відомих українських імен, розкрити значення свого імені); “Змінити співрозмовника” (ефективний для роботи слухачів у групах), “Портрет” (опис зовнішності й характеру реальної людини або фотопортрета, картини) та ін. Також залучаємо для вивчення лексики й граматики різноманітні аудіоматеріали, що репрезентують певну комунікативну ситуацію, записи спонтанного мовлення, відеозаписи (напр., новини, уривки художніх, науково-популярних та мультиплікаційних фільмів тощо). Слухачам подобається вчити й виконувати тексти українських народних пісень (Tu ж мене підманула, Ой на горі два дубки), інсценізувати дитячі казки (Колобок, Рукавичка), моделювати типові ситуації, напр.: Ранок у сім' $\dddot{\imath}$, Вечір у сім $\dddot{\imath}$ тощо.

Новітні методи й технології докладно описують Т. Касьяненко, Т. Кудіна, Л. Мацько та ін. [Мацько, Кудіна 2011; Касьяненко 2013]. Т. Касьяненко звертає увагу на те, що сьогодні все більшого поширення у викладанні УМІ набуває метод навчання із застосуванням комп’ютера. „Інструментальні засоби, у тому числі при вивченні української мови як іноземної, складаються 3 багатьох компонентів, серед яких виокремлюють: 1) реєстрацію користувачів; 2) засоби адміністрування; 3) подання навчальних матеріалів; 4) засоби тестування та оцінювання знань користувачів; 5) засоби тренування та навчання; 6) зберігання статистичних даних про результати тестування користувачів. Інструментальні засоби для навчання та тестування дають змогу викладачам, зокрема, генерувати тестові завдання з бази даних за критеріями, 
заданими розробником курсу; використовувати тестові завдання різних типів (вибір одного варіанта із запропонованих, вибір кількох варіантів із запропонованих, уведення відповіді); включати малюнки, анімацію, аудіо- та відеофайли; користуватися в режимі навчання контекстною допомогою; видавати (у режимі контролю) в кінці тесту статистичні дані про результати тестування, які записуються в базу даних результатів; указувати час для виконання тесту. Студентам-іноземцям це дає змогу здійснювати контроль над засвоєнням знань (у режимі on-line), а викладачам забезпечує можливість доступу та редагування баз даних із запитаннями; визначення критеріїв вибору завдань; перегляду бази даних реєстраційних форм; здійснення адміністрування цих баз даних тощо” [Касьяненко 2013].

Вивчення іноземної мови завжди пов'язане 3 відкриттям культури іï народу-носія. Л. Селіверстова із цього приводу пише: „Зважаючи на те, що мова виконує дві найважливіші функції - комунікативну й кумулятивну, іноземці мають вивчати українську мову не тільки як новий код - спосіб вираження думки 3 метою навчання, a i як джерело повідомлень про українську культуру. Для того, щоб наблизитися до нової культури, світогляду, світосприйняття, недостатньо засвоїти лише план вираження змісту мовних явищ. Необхідне засвоєння й плану змісту — нової системи понять, тобто концептуальної картини світу, що покладено в їхню основу” [Селіверстова 2007: 9]. Отже, за порівняно короткий період (10 місяців) потрібно ввести іноземних студентів до мовно-концептуальної картини світу, мову якої вони опановують.

На специфіку роботи зі слухачами підготовчого відділення звертає увагу також Ю. Трубнікова: „Перед викладачем української мови як іноземної стоїть завдання не лише максимально ознайомити студента з особливостями мови на початковому етапі навчання, але й сформувати загальне сприйняття культурно-національного середовища. Це, на наш погляд, можна реалізувати насамперед через добір відповідного лексичного матеріалу, опрацювання текстів, що сприятимуть ефективності цього процесу” [Трубнікова 2013: 27]. Отже, комунікативний та культурологічний (лінгвокраїнознавчий) підходи в процесі навчання УМІ стають визначальними й взаємопов'язаними. Застосування матеріалів 3 лінгвокраїнознавства допомагає іноземним студентам адаптуватися до нового мовно-культурного середовища. Лінгвокраїнознавчий підхід, методи й прийоми навчання лексики з національно-культурним змістом, урахування міжмовних та міжкультурних паралелей викладено в монографії Г. Онкович, у статтях А. Бронської, Н. Данилюк, О. Смолінської та ін. [Онкович 1997; Бронська 2000; Смолінська 2002; Данилюк 2012; Данилюк 2014; Данилюк 2016]. У багатьох 3ВО України на підготовчому відділенні, а також під час навчання на факультетах іноземці слухають курси країнознавства або лінгвокраїнознавства, що відповідно методично забезпечені підручниками й посібниками, які місять відповідну інформацію про Україну, напр.: Країнознавство для слухачів підготовчого відділення 
(Л. Азарова, Л. Горчинська та ін., Вінниця 2010), Знайомтесь: Украйна (Н. Ушакова, І. Петров, Харків 2012) та про міста, у яких вони перебувають: Місто Лева (Г. Бойко та ін., Львів 2013), Харків. Перші кроки (В. Тараненко, Л. Солодова, Т. Доценко, Харків 2011), Знайомтеся: Кийв (Г. Швець, Київ 2011), Суми - нова мова, нові друзі, нове життя (Л. Біденко та ін., Суми 2018) та ін.

Основним засобом подання лінгвокраїнознавчої інформації, як відомо, $€$ текст.Задопомогоюспеціальнодібранихоригінальних таадаптованих текстів можна познайомити іноземців 3 досягненнями української науки та культури, постатями видатних людей України у сфері науки, освіти, літератури, фольклору, мистецтва, спорту та ін. 3 такою метою використовуємо названі вище посібники, однак їхні тексти потрібно адаптувати для початкового рівня слухачів підготовчого відділення. Тому ми уклали свої тексти, зокрема 3 такими назвами: Луцьк, Східноєвропейський нащіональний університет імені Лесі Украӥнки, Леся Українка, Музей Лесі Украйнки, Волинь. Вони дають змогу слухачам познайомитися зі специфікою нашого регіону. Корисними є й лексикографічні праці, що теж потребують адаптування до початкового рівня: Лінгвокраӥнознавчий словник власних назв украӥнської мови (сім зошитів видали викладачі ЛНУ імені І. Франка, Львів 2006-2016), лінгвокраїнознавчі словники, укладені $Н$. Данилюк й авторським колективом Украӥна в словах (Київ 2004), Украӥна від А до Я (Луцьк 2014), статті Н. Данилюк та I. Процик про використання лінгвокраїнознавчих словників для вивчення УМІ [Процик 2011; Данилюк 2014].

Методи й принципи навчання УМІ реалізовані в навчальних підручниках і посібниках, якими найактивніше послуговуються викладачі СНУ імені Лесі Українки на підготовчому відділенні: В. Вінницька Слухаємо, говоримо, пишемо (украӥнська мова як іноземна) (Київ 2003); Н. Зайченко, С. Воробйова Практичний курс украӥнської мови для іноземиів: усне мовлення (Київ 2005); Вступний курс з украйнської мови для студентів-іноземців підготовчого відділення (ред. Т. Дегтярьова, Суми 2010); Н. Лисенко, Р. Кривко, С. Світлична, Т. Цапко Українська мова для іноземиів (Київ 2010) та ін. Для того, щоб слухачам було легше сприймати матеріал поряд з власне українськими використовуємо посібники, у яких пояснення наведені англійською мовою: O. Bekh, J. Dingley Ukrainian. Teach youself (London 2007), Let's speak Ukrainian (1 част. - Київ 2010), Ukrainian elementary. Ukrainian for Foreigners. Украӥнська мова для іноземиів (Київ 2017).

Оскільки матеріалів для франкомовних іноземців, які вивчають українську мову, обмаль, Н. Данилюк і Д. Пуфалт (викладач з Канади, який упродовж багатьох років працював у СНУ імені Лесі Українки) підготували до друку навчальний посібник з паралельними коментарями англійською та французькою мовами, що незабаром вийде у світ. У процесі вивчення словникового складу УМІ для пояснення значень слів, добирання синонімів й антонімів, перекладан- 
ня текстів залучаємо, крім названих, словники синонімів й антонімів, перекладні, тлумачні, тематичні тощо. Зазначмо, що викладачі СНУ імені Лесі Українки видали англійсько-український словник - навчальний посібник для іноземців, у якому, крім слів та їхніх значень, подано й сталі вислови, а також усі граматичні форми, що викликають труднощі: English-Ukrainian Reference Dictionary for Foreigners (укл. Є. Гороть, Н. Данилюк, І. Калиновська та ін., Луцьк 2016). Для закріплення вивченого матеріалу слухачі підготовчого відділення виконують вправи й завдання. Услід за О. Туркевич [Туркевич 2012], їх об'єднуємо в такі групи: 1) за способом виконання: усні та письмові; 2) за призначенням: тренувальні, контрольні; 3) за місцем виконання: аудиторні та домашні; 4) за способом виконання: індивідуальні, парні, групові; 5) за мовними рівнями: фонетичні / лексичні / граматичні / синтаксичні; 6) за способом виконання: вправи за зразком, конструктивні, творчі; 7) за належністю до виду мовленнєвої діяльності: вправи для аудіювання, читання, письма, говоріння (часто їх комбінуємо); 8) за розміщенням щодо тексту: дотекстові, притекстові, післятекстові; 9) за наявністю моделей та відповідей: інструкція, зразок, коментар, ключ до вправи, відповідь до вправи; 10) за призначенням: контрольні й тренувальні завдання та ін. Крім вправ і завдань, уміщених у підручниках і посібниках, пропонуємо ті, які ми підготували для роботи зі слухачами.

У лінгводидактиці вже вироблено теоретичні засади, а в численних статтях, кількох дисертаціях і монографіях з методики викладання УМІ виділено й обгрунтовано ключові термінопоняття. Для роботи зі слухачамиіноземцями на підготовчому відділенні створено належну навчальнометодичну базу (підручники, посібники, словники, програми), затверджено навчальні плани й стандарти. Традиційні методи навчання на сучасному етапі доповнено інтерактивними методами, що передбачають використання нових засобів: технічних (комп'ютера, мультимодальних систем) i комунікаційних (мережі інтернету). Для кращого опанування українською мовою та іiі культурою (нормами) активізовано комунікативний та лінгвокраїнознавчий підходи, які набувають усе більшого поширення, що й відображено у відповідних навчально-методичних матеріалах. Перспективу дослідження вбачаємо в докладному описуванні методів і прийомів навчання іноземних студентів на кожному мовному рівні, а також підготуванні нових праць для забезпечення процесу навчання.

\section{Список використаної літератури}

Бронська А., Лінгвокраїнознавчий аспект у викладанні української мови як іноземної, [в:] „Дивослово”, 2000, № 7, с. 43-44.

Бронська А.А., Теоретичніоснови базовоїметодичної підготовки викладачівукраӥнської та російської мов як іноземних, Київ: Редакція „Бюлетень Вищої атестаційної комісії України”, вид-во „Толока”, 2002. 
Гнаткевич Ю. В., Навчання лексичного аспекту чужоземної мови у вищих навчальних закладах, Київ: Вид. центр „Просвіта”, 1999.

Данилюк Н., Використання лінгвокраӥнознавчого словника у прочесі вивчення украӥнської мови як іноземної, [в:] „Теорія і практика викладання української мови як іноземної”, 2014, вип. 10, с. 160-169.

Данилюк Н. О., Лексика з національно-культурним змістом на початковому етапі вивчення української мови іноземиями, [в:] „Науковий часопис Національного педагогічного університету імені М. П. Драгоманова”, сер. 10. „Проблеми граматики і лексикології української мови”, 2012, вип. 9, с. 186-189.

Данилюк Н., Міжмовні та міжкультурні паралелі на початковому етапі навчання української мови арабських студентів, [в:] „Теорія і практика викладання української мови як іноземної”, 2016, № 12, с. 257-264.

Зайченко Н. Ф., Присяжнюк Н. К., Питання украӥнознавства в аспекті лінгводидактики слов'янських мов, [в:] Краківські украӥнські зошити, Краків: Швайпольт Фіоль, 1995, т. III-IV, c. 36-43.

Касьяненко Т., Викладання украӥнської мови як іноземної: принципи оптимізації та інновації, [в:] „Культура народов Причерноморья”, 2013, № 257, с. 7-10.

Космеда Т., Від 20-річчя до 25-річчя: досягнення познанської украӥністики (2011-2016), [в:] „Studia Ukrainica Poznaniensia”, 2017, zesz. V, s. 7-17.

Кочан I., Становлення і розвиток методики викладання украӥнської мови як іноземної, [в:] „Теорія і практика викладання української як іноземної”, 2012, вип. 7, с. 17-23.

Кочерган М. П., Загальне мовознавство, Київ: Академія, 2006.

Мацько Л., Кудіна Т., Інновачійні технології викладання украӥнської мови як іноземної на підготовчому відділенні університету, [в:] „Теорія і практика викладання української мови як іноземної”, 2011, вип. 6, с. 229-238.

Онкович Г., Українознавство і лінгводидактика, Київ: Логос, 1997.

Паламар Л. М., Лінгводидактичні основи формування україномовної особистості, Київ: НПЦ „Київський університет”, 1997.

Процик І., Лінгвокраӥнознавчий словник власних назв украӥнської мови в навчальній лексикографії для чужсоземиів, [в:] „Вісник Львівського університету”, сер. філол., 2011, вип. 52, с. 388-394.

Сокіл Б., Методи вивчення украӥнської мови як іноземної та їх характеристика, [в:] „Теорія і практика викладання української мови як іноземної”, 2007, вип. 2, с. 14-18.

Селіверстова Л., Лінгвістична та психологічна основа навчання украӥнської мови як іноземної, [в:] „Теорія і практика викладання української мови як іноземної”, 2007, вип. 2, с. 8-13.

Смолінська О., Лінгвокраїнознавство у навчанні украӥнськоїмови як іноземної, [в:] „Рідна школа", 2002, № 2, с. 43-45.

Строганова Г., Концептуальні підходи до засвоєння украӥнської мови іноземними студентами, [в:] „Теорія і практика викладання української мови як іноземної”, 2008, вип. 3 , с. $173-179$.

Трубнікова Ю. О., Застосування комунікативної методики як однієї з найефективніших методик при викладанні української мови іноземним студентам на підготовчому 
відділенні, [в:] „Вісник Дніпропетровського університету імені Альфреда Нобеля”, сер. „Педагогіка і психологія”, 2013, № 1 (5), с. 27-30.

Туркевич О. В., Еволюція термінолексики методики викладання украӥнськоӥ мови як іноземної, автореф. ... канд. філол. наук, Львів 2012.

Туркевич О. В., Методика викладання украӥнської мови як іноземної: проблеми унормування термінолексики, [в:] „Науковий часопис Національного педагогічного ун-ту ім. М. П. Драгоманова”, сер. 10, „Проблеми граматики і лексикології української мови", 2012, вип. 9, с. 247-249.

Швець Г. Д., Становлення методики викладання украӥнської мови як іноземної, [в:] Електронний ресурс: НБУВ, http://www.irbis-nbuv.gov.ua/cgi-bin/irbis_nbuv/cgiirbis_64.exe?I $21 \mathrm{DBN}=\mathrm{LINK} \& \mathrm{P} 21 \mathrm{DBN}=\mathrm{UJRN} \& \mathrm{Z} 21 \mathrm{ID}=\& \mathrm{~S} 21 \mathrm{REF}=10 \& \mathrm{~S} 21 \mathrm{CNR}=20 \& \mathrm{~S} 21 \mathrm{STN}=1 \& \mathrm{~S} 2$ $1 \mathrm{FMT}=\mathrm{ASP}$-meta\&C21COM=S\&2_S21P03=FILA=\&2_S21STR=pspo_2013_39(4)_60 (14.09.2018).

\section{Spysok vykorystanoi literatury [References]}

Bronska A., Linhvokrainoznavchyi aspekt u vykladanni Ukrainskoi movy yak inozemnoi [Linguistic Country Studies Aspect in Teaching Ukrainian as a Foreign Language], [v:] „Dyvoslovo”, 2000, № 7, s. 43-44.

Bronska A. A., Teoretychni osnovy bazovoi metodychnoi pidhotovky vykladachiv ukrainskoi ta rosiiskoi mov yak inozemnykh [Theoretical Bases of Basic Methodical Preparation of Teachers of Ukrainian and Russian as Foreign Languages], Kyiv: Redaktsiia „Biuleten Vyshchoi atestatsiinoi komisii Ukrainy”, vyd-vo „Toloka”, 2002.

Hnatkevych Yu. V., Navchannia leksychnoho aspektu chuzhozemnoi movy u vyshchykh navchalnykh zakladakh [Teaching Lexical Aspect of Foreign Language in Higher Educational Institutions], Kyiv: Vyd. tsentr „Prosvita”, 1999.

Danyliuk N., Vykorystannia linhvokrainoznavchoho slovnyka u protsesi vyvchennia ukrainskoi movy yak inozemnoi [Linguistic Country Studies Dictionaries Using in the Process of Studying the Ukrainian Language as a Foreign Language], [v:] „Teoriia i praktyka vykladannia ukrainskoi movy yak inozemnoi”, 2014, vyp. 10, s. 160-169.

Danyliuk N. O., Leksyka z natsionalno-kulturnym zmistom na pochatkovomu etapi vyvchennia ukrainskoi movy inozemtsiamy [Leksyks with National and Cultural Content at the Initial Stage of Studying the Ukrainian Language by Foreigners], [v:] „Naukovyi chasopys Natsionalnoho pedahohichnoho universytetu imeni M. P.Drahomanova”, ser. 10. „Problemy hramatyky i leksykolohii ukrainskoi movy”, 2012, vyp. 9, s. 186-189.

Danyliuk N., Mizhmovni ta mizhkulturni paraleli na pochatkovomu etapi navchannia ukrainskoi movy arabskykh studentiv [Interlingual and Intercultural Parallels at the Initial Stage of Teaching the Ukrainian Language of Arab Students], [v:] „Teoriia i praktyka vykladannia ukrainskoi movy yak inozemnoi”, 2016, № 12, s. 257-264.

Zaichenko N. F., Prysiazhniuk N. K., Pytannia ukrainoznavstva v aspekti linhvodydaktyky slovianskykh mov [The Issue of Ukrainian Studies in the Aspect of the Lingvodidactics 
of the Slavic Languages], [v:] Krakivski ukrainski zoshyty, Krakiv: Shvaypolt Fiol, 1995, t. III-IV, s. 36-43.

Kasianenko T., Vykladannia ukrainskoi movy yak inozemnoi: pryntsypy optymizatsii ta innovatsii [Teaching Ukrainian as a Foreign Language: Principles of Optimization and Innovation], [v:] „Kultura narodov Prichernomor'ya ”, 2013, № 257, s. 7-10.

Kochan I., Stanovlennia i rozvytok metodyky vykladannia ukrainskoi movy yak inozemnoi [Formation and Development of the Methodology of Teaching Ukrainian as a Foreign Language], [v:] „Teoriia i praktyka vykladannia ukrainskoi yak inozemnoi”, 2012, vyp. 7, s. $17-23$.

Kocherhan M.P.,Zahalne movoznavstvo [General Linguistics], Kyiv: Akademiia, 2006.

Kosmeda T., Vid 20-richchia do 25-richchia: dosyahnennia poznanskoi ukrayinistyky (20112016)[From 20 years to 25-years: Achievements of Poznan Ukrainian Studies], [в:] „Studia Ukrainica Poznaniensia", 2017, zesz. V, s. 7-17.

Matsko L., Kudina T., Innovatsiini tekhnolohii vykladannia ukrainskoi movy yak inozemnoi na pidhotovchomu viddilenni universytetu [Innovative Technologies of Teaching Ukrainian as a Foreign Language at the Preparatory Department of the University], [v:] ,Teoriia i praktyka vykladannia ukrainskoi movy yak inozemnoi”, 2011, vyp. 6, s. 229-238.

Onkovych H., Ukrainoznavstvo i linhvodydaktyka [Ukrainian Studies and Linguodidactics], Kyiv: Lohos, 1997.

Palamar L. M., Linhvodydaktychni osnovy formuvannia ukrainomovnoi osobystosti [Lingvo Didactic Basis for the Formation of a Ukrainian-Speaking Personality], Kyiv: NPTs „Kyivskyi universytet”, 1997.

Protsyk I., Linhvokrainoznavchyi slovnyk vlasnykh nazv ukrainskoi movy $v$ navchalnii leksykohrafii dlia chuzhozemtsiv [Linguistic Country Studies Dictionary of the Proper Names of the Ukrainian Language in the Educational Lexicography for Foreigners], [v:] „Visnyk Lvivskoho universytetu”, ser. filol., 2011, vyp. 52, s. 388-394.

Sokil B., Metody vyvchennia ukrainskoi movy yak inozemnoi ta yikh kharakterystyka [Methods of Studying the Ukrainian Language as a Foreign Language and their Characteristics], [v:] „Teoriia i praktyka vykladannia ukrainskoi movy yak inozemnoi”, 2007, vyp. 2, s. 14-18.

Seliverstova L., Linhvistychna ta psykholohichna osnova navchannia ukrainskoi movy yak inozemnoi [Linguistic and Psychological Basis of Teaching Ukrainian as a Foreign Language], [v:] „Teoriia i praktyka vykladannia ukrainskoi movy yak inozemnoi”, 2007, vyp. 2, s. 8-13.

Smolinska O., Linhvokrainoznavstvo u navchanni ukrainskoi movy yak inozemnoi [Linguistic Country Studies Dictionaries in the Teaching of the Ukrainian Language as a Foreign Language], [v:] „Ridna shkola”, 2002, № 2, s. 43-45.

StrohanovaH., Kontseptualni pidkhodydo zasvoiennia ukrainskoimovyinozemnymy studentamy [Conceptual Approaches to Studying of Ukrainian Language by Foreign Students], [v:] „Teoriia i praktyka vykladannia ukrainskoi movy yak inozemnoi”, 2008, vyp. 3, s. 173-179.

Trubnikova Yu. O., Zastosuvannia komunikatyvnoi metodyky yak odniiei z naiefektyvnishykh metodyk pry vykladanni ukrainskoi movy inozemnym studentam na pidhotovchomu 
viddilenni [Application of the Communicative Methodology as One of the Most Effective Methods in Teaching Ukrainian Language of Foreign Students at the Preparatory Department], [v:] „Visnyk Dnipropetrovskoho universytetu imeni Alfreda Nobelia”, ser. „Pedahohika i psykholohiia”, 2013, № 1 (5), s. 27-30.

Turkevych O. V., Evoliutsiia terminoleksyky metodyky vykladannia ukrainskoi movy yak inozemnoi [Evolution of Terminology of Methods of Teaching Ukrainian as a Foreign Language], avtoref. ... kand. filol. nauk, Lviv 2012.

Turkevych O. V., Metodyka vykladannia ukrainskoi movy yak inozemnoi: problemy unormuvannia terminoleksyky [Methodology of Teaching Ukrainian as a Foreign Language: Problemy of Norms of Terminology Vocabulary], [v:] „Naukovyi chasopys Natsionalnoho pedahohichnoho un-tu im. M. P. Drahomanova”, ser. 10, „Problemy hramatyky i leksykolohii ukrainskoi movy”, 2012, vyp. 9, s. 247-249.

Shvets H. D., Stanovlennia metodyky vykladannia ukrainskoi movy yak inozemnoi [Development of the Methodology of Teaching Ukrainian as a Foreign Language], [v:] Elektronnyi resurs: NBUV, http://www.irbis-nbuv.gov.ua/cgi-bin/irbis_nbuv/cgiirbis_64.exe?I21DBN=LINK $\& \mathrm{P} 21 \mathrm{DBN}=\mathrm{UJRN} \& Z 21 \mathrm{ID}=\& \mathrm{~S} 21 \mathrm{REF}=10 \& \mathrm{~S} 21 \mathrm{CNR}=20 \& \mathrm{~S} 21 \mathrm{STN}=1 \& \mathrm{~S} 21 \mathrm{FMT}=\mathrm{ASP}$ meta\&C21COM=S\&2_S21P03=FILA=\&2_S21STR=pspo_2013_39(4)_60 (14.09.2018). 